\title{
PENGELOLAAN PEMBIAYAAN PENDIDIKAN DI MTS AL-IKHLAS CAMPAKA
}

\author{
Moh. Sugandi* \& Susanti** \\ UIN Sunan Gunung Djati Bandung \\ *sugandiqobul@gmail.com \\ **susanti.duo93@gmail.com
}

\begin{abstract}
MTs Al-Ikblas has income derived from BOS and student information. Based on the results of an exploratory study in MTs Al-Ikblas madrasa financing management, MTs Al-Ikblas was considered less effective in managing madrasa finance. aims to describe education funding planning, Describe the implementation of education funding, Describe financing responsibilities, Describe. Data collection techniques using interview techniques, observation and documentation. Funding Management in MTs Al-Ikblas Campaka is carried out by process: Budgeting (Budget planning): Financing financing has been carried out properly and transparently, Source of Funding is obtained from several sources namely: source of funds from the community (SPP), sources of funding from the government in the form of BOS funds , The implementation of the financing based on the budget that has been made (RKAS), the supervision and accountability of funding is carried out by the principal and the foundation. Funding management has been carried out transparently, effectively and efficiently. When planning involves parties who represent the parts in school. Funding management is also still lacking, not all posts are stated in the RKAS, because there are still expenditures outside the RKAS for the KBM smoothness process. Supporting and Inhibiting Factors. Supporting factors in financing management: schools have the right to regulate school funding according to school needs without being totally dependent on the foundation. Inbibiting factors in financing management: non-current funding sources, both BOS funding and student delays in SPP payments.
\end{abstract}

\section{Keyword: Management, Financing, Education}

Abstrak : MTs Al-Ikhlas memiliki pemasukan yang berasal dari BOS dan infaq siswa. Berdasarkan hasil studi eksplorasi di MTs Al-Ikhlas manajemen pembiayaan madrasah, MTs Al-Ikhlas dirasa kurang efektif dalam mengelola keuangan madrasah. bertujuan untuk mendeskripsikan perencanaan pembiayaan pendidikan, Mendeskripsikan pelaksanaan pembiayaan pendidikan, Mendeskripsikan pertanggungjawaban pembiayaan, Mendeskripsikan. Teknik pengumpulan data menggunakan teknik wawancara, observasi dan dokumentasi. Pengelolaan Pembiayaan di MTs Al-Ikhlas Campaka dilaksanakan dengan proses :Penganggaran (Perencanaan anggaran): Penganggaran pembiayaan telah dilaksanakan secara baik dan transparan, Sumber Pembiayaan diperoleh dari beberapa sumber yaitu :sumber dana dari masyarakat (SPP), sumber dana dari pemerintah berupa dana BOS,Pelaksanaan pembiayaan di berdasarkan anggaran yang sudah dibuat (RKAS),Pengawasan dan Pertanggungjawaban pembiayaan dilakukan kepala sekolah dan

Manazhim : Jurnal Manajemen dan Ilmu Pendidikan

Volume 1, Nomor 2, Agustus 2019; 142-151

https://ejournal.stitpn.ac.id/index.php/manazhim 
yayasan. Pengelolaan pembiayaan sudah dilaksanakan secara transparan, efektif dan efisien. Pada saat perencanaan sudah melibatkan pihak pihak yang mewakili bagian- bagian yang ada di sekolah. Pengelolaan pembiayaan juga masih ada kekurangannya yaitu belum semua pos dituangkan dalam RKAS, karena masih ada pengeluaran di luar RKAS untuk proses kelancaran KBM Faktor pendukung dan Penghambat. Faktor pendukung dalam pengelolaan pembiayaan: sekolah berhak mengatur pembiayaan sekolah sesuai dengan kebutuhan sekolah tanpa tergantung seutuhnya pada pihak yayasan. Faktor penghambat dalam pengelolaan pembiayaan :tidak lancar sumber dana pembiayaan baik turunnya dana BOS maupun keterlambatan siswa dalam pembayaran SPP.

Kata Kunci: Pengelolaan, Pembiayaan, Pendidikan

\section{PENDAHULUAN}

Manusia sebagai makhluk individu dan makhluk sosial tidak dapat hidup sendiri, manusia memerlukan makhluk lain untuk hidup. Kodrat manusia sebagai makhluk hidup memerlukan makhluk lain untuk berkomunikasi dan berinteraksi. Interaksi yang terjadi baik antara manusia dengan tuhan, manusia dengan manusia, manusia dengan lingkungan, atau manusia dengan makhluk lainnya baik disengaja maupun tidak disengaja. Bentuk interaksi manusia dengan sengaja dilakukan melalui pendidikan. Manusia menyadari bahwa pendidikan sangat penting untuk perkembangan dan pertumbuhan potensi pada diri manusia, karena tanpa ada pendidikan perkembangan dan pertumbuhan akan menjadi lemah.

Pendidikan merupakan unsur utama dalam pengembangan sumber daya manusia. Semua yang dilakukan manusia tidak lepas dari dunia pendidikan, baik disadari maupun tidak. Manusia memulai proses pendidikannya sejak lahir hingga ke liang lahat. Hal itu dilakukan untuk meningkatkan kemampuannya dalam hal sikap, perilaku, wawasan, kemampuan, keterampilan baik secara formal maupun informal. Pendidikan merupakan hak bagi setiap orang, tidak peduli miskin maupun kaya, semua mempunyai kesempatan untuk memperoleh hak yang sama untuk mendapatkan pendidikan. Pendidikan menurut Mahmud menyatakan bahwa pendidikan pada dasarnya merupakan interaksi antara faktorfaktor yang terlibat di dalamnya untuk mencapai tujuan. Proses sederhana yang menggambarkan interaksi unsur pendidikan dapat secara jelas dilihat dalam proses belajar mengajar yang terjadi di lembaga pendidikan formal, tepatnya di kelas yaitu guru 
mengajarkan nilai-nilai ilmu dan keterampilan kepada anak didik dan anak didik menerima pengajaran tersebut terjadilah apa yang dinamakan proses belajar. ${ }^{1}$

Pendidikan menurut Fattah mengungkapkan bahwa pendidikan dirumuskan sebagai proses pengembangan dan latihan yang mencakup aspek pengetahuan (knowledge), keterampilan (skill), dan kepribadian (character), terutama dilakukan dalam suatu bentuk formula (persekolahan) kegiatan pendidikan mencakup proses dalam menghasilkan (production) dan transfer (distribution) ilmu pengetahuan yang dilakukan oleh individu atau organisasi belajar (learning organization). ${ }^{2}$

Pendidikan berdasarkan definisi di atas mengandung pengertian yang luas, karena pendidikan terdiri dari unsur-unsur pendidikan yang terkait satu dengan yang lain. Unsurunsur pendidikan terdiri dari pengajar, pengetahuan, siswa dan media pengajaran. Pendidikan mempunyai pengertian yang lebih luas dari pengajaran karena dalam pendidikan tidak hanya ditekankan pada aspek intelektualitas saja tetapi juga mencakup proses pembinaan kepribadian siswa secara menyeluruh. Dalam pendidikan proses latihan dan pengembangan mencakup unsur pengetahuan, keterampilan, kepribadian untuk menghasilkan pendidikan yang berkualitas.

Pendidikan yang layak tidak terlepas dari pembiayaan. Biaya merupakan unsur yang penting dalam penyelenggaraan pendidikan. Penentuan biaya akan memengaruhi tingkat efektifitas kegiatan dalam suatu organisasi, kegiatan yang dilaksanakan dengan menggunakan biaya yang relatif rendah tetapi menghasilkan produk yang berkualitas maka kegiatan tersebut dikatakan efektif dan efisien. Menurut Suhardan biaya pendidikan adalah total biaya yang dikeluarkan baik oleh individu peserta didik, keluarga yang menyekolahkan anak, warga masyarakat perorangan, kelompok masyarakat maupun yang dikeluarkan pemerintah untuk kelancaran pendidikan. ${ }^{3}$ Pembiayaan pendidikan diperlukan untuk membantu proses kelancaran pelaksanaan pendidikan. Biaya pendidikan dikeluarkan oleh individu, masyarakat maupun pemerintah. Dalam pembiayaan pendidikan berkaitan dengan perencanaan pembiayaan, pelaksanaan dan pengawasan anggaran pendidikan.

Sekolah sebagai lembaga pendidikan harus mampu menyusun sistem informasi keuangan standar, maka diperlukan pembenahan manajemen keuangan dengan cara

\footnotetext{
${ }^{1}$ Mahmud, Metode Penelitian Pendidikan, (Bandung: CV Pustaka Setia, 2011), 52.

${ }^{2}$ Nanang Fattah, Ekonomi \& Pembiayaan Pendidikan, (Bandung: PT Remaja Rosdakarya Offset, 2012), 14.

${ }^{3}$ Suhardan dkk., Ekonomi dan Pembiayaan Pendidikan (Bandung: Alfabeta, 2012), 22.
} 
menyusun teknik-teknik pengelolaan keuangan sekolah yang sesuai dengan standar keuangan yang berlaku.

Pembiayaan pendidikan adalah faktor penting dalam menjamin mutu dan kualitas pendidikan. Penyelenggaraan pendidikan, pengelolaan keuangan dan pembiayaan tidak terlepas dari manajemen pendidikan, karena pembiayaan merupakan komponen yang menjamin terlaksananya proses kegiatan belajar mengajar di sekolah. Pembiayaan pendidikan merupakan aktivitas yang berkenaan dengan perolehan dana (pendapatan) yang diterima dan bagaimana penggunaan dana tersebut dipergunakan untuk membiayai seluruh program pendidikan yang telah ditetapkan. ${ }^{4}$

Kepala sekolah sebagai pimpinan dalam lembaga pendidikan harus mempunyai kemampuan untuk mengelola keuangan sekolah dalam rangka melaksanakan pembiayaan sekolah. Kepala sekolah mempunyai wewenang untuk mencari dan memanfaatkan sumber dana sesuai dengan kebutuhan sekolah masing-masing. Pengelolaan keuangan sekolah meliputi proses perencanaan, pelaksanaan, pengawasan, dan evaluasi. Tujuan utama pengelolaan pembiayaan pendidikan adalah bagaimana pembiayaan pendidikan dapat menghasilkan produktifitas pendidikan. Produktifitas pendidikan berkaitan dengan proses penataan dan penggunaan sumber-sumber pendidikan untuk mencapai tujuan pendidikan secara efisien dan efektif.

MTs Al-Ikhlas memiliki pemasukan yang berasal dari BOS dan infaq siswa. Berdasarkan hasil studi eksplorasi di MTs Al-Ikhlas manajemen pembiayaan madrasah, MTs Al-Ikhlas dirasa kurang efektif dalam mengelola keuangan madrasah.

Berdasarkan uraian di atas, penelitian ini bertujuan untuk : (1) mendeskripsikan perencanaan pembiayaan pendidikan di MTs Al-Ikhlas Campaka, (2) Mendeskripsikan pelaksanaan pembiayaan pendidikan di MTs Al-Ikhlas Campaka, (3) Mendeskripsikan pertanggungjawaban pembiayaan di MTs Al-Ikhlas Campaka, (4) Mendeskripsikan kendala yang dihadapi dalam pengelolaan pembiayaan di MTs Al-Ikhlas Campaka.

${ }^{4}$ Akdon dkk., Manajemen Pembiayaan Pendidikan, (Bandung: Remaja Rosdakarya. 2017), 23. 


\section{METODE DAN PENDEKATAN PENELITIAN}

Penelitian ini menggunakan penelitian kualitatif. Bertujuan untuk mengetahui pengelolaan pembiayaan pendidikan di MTs Al-Ikhlas Campaka. Wujud data dalam penelitian penelitian kualitatif berupa kata demi kata bukan dalam bentuk rangkaian angka, kemudian peneliti menyusunnya dalam bentuk teks yang dikembangkan ${ }^{5}$. Sumber data utama dalam penelitian kualitatif adalah kata-kata dan tindakan selebihnya adalah data tambahan seperti dokumen dan lain-lain.

Narasumber dapat dimintai keterangan mengenai pengelolaan pembiayaan sekolah yang terdiri dari Kepala Sekolah, Bendahara Sekolah, guru, karyawan, komite sekolah dan siswa. Teknik pengumpulan data dalam penelitian ini digunakan dengan menggunakan teknik wawancara, observasi dan dokumentasi. Analisis data dilakukan dengan tahapan Miles dan Huberman yaitu meliputi: reduksi data, penyajian data dan penarikan kesimpulan atau verifikasi. ${ }^{6}$ Dalam penelitian ini penulis menggunakan trianggulasi data atau sumber dan trianggulasi metode, yang diperoleh dari kepala sekolah, bendahara sekolah, komite dan sumber lain dengan wawancara mendalam, serta observasi dan mengkaji dokumen dan arsip.

Pengecekan keabsahan data diperlukan teknik pemeriksaan. Pelaksanaan teknik pemeriksaan data didasarkan atas sejumlah kriteria tertentu. Teknik keabsahan data menurut Moleong ada empat kriteria yang digunakan yaitu derajat kepercayaan (credibility), keteralihan (transferability), kebergantungan (defendability) dan kepastian (confirmability). ${ }^{7}$

\section{HASIL DAN PEMBAHASAN}

MTs Al-Ikhlas Campaka adalah lembaga pendidikan dibawah naungan kemenag, proses pengelolaan pembiayaan di MTs Al-Ikhlas Campaka meliputi:

\section{Proses perencanaan pembiayaan di MTs Al-Ikhlas Campaka}

Proses perencanaan pembiayaan di MTs Al-ikhlas Campaka di peroleh informasi melalui wawancara dengan pihak terkait tentang proses penganggaran atau perencanaan pembiayaan. Perencanaan pembiayaan dimulai dengan rapat kordinasi untuk menentukan RKAS yang melibatkan Kepala Sekolah, wakil kepala

\footnotetext{
${ }^{5}$ Sutama, Metode Penelitian Pendidikan Kuantitatif, Kualitatif, PTK, R \& D, (Kartasura: Fairuz Media, 2015), 126.

${ }^{6}$ Milles dan Huberman, Analisis Data Kualitatif, (Jakarta: Universitas Indonesia Press, 1992), 16.

${ }^{7}$ Lexy Moleong, Metodologi Penelitian Kualitatif. (Bandung: PT Remaja Rosdakarya, 2014), 324.
} 
sekolah, Bendahara, Komite sekolah, kepala tata usaha, dan perwakilan yayasan. Rapat koordinasi tersebut membahas RKAS sekolah yang berisi tentang sumber dana untuk membiayai pendidikan dan pengalokasian dana sesuai dengan kebutuhan sekolah. Tim tersebut bekerja membuat rincian kegiatan selama satu tahun dan merencanakan estimasi dana sesuai dengan sumber dana yang ada. Dalam tim ini dibagi sesuai dengan kapasitasnya masing-masing. Wakil Kepala bagian sarana prasarana misalnya, akan membuat draf anggaran berapa jumlah sarana prasarana yang dibutuhkan dalam satu tahun serta berapa jumlah dana yang dibutuhkan, kemudian dibawa ke tim yang akan dipertimbangkan berapa sarana prasarana yang akan diutamakan dan berapa biaya yang dianggarkan sesuai dengan sumber dana yang ada.

Proses perencanaan pembiayaan sesuai dengan pendapat Cann dalam penelitiaanya yang berjudul Policy Venues and Policy Change: The Case of Education Finance Reform mengemukakan bahwa kebijaksanan hasil reformasi keuangan di rancang oleh pihak-pihak yang berkepentingan yaitu melalui pengadilan, legeslatif dan pemilihan atau referendum. Semua pihak terkait bekerja sama untuk merencanakan reformasi kebijakan dalam tahun tertentu kemudian dianalisis secara menyeluruh untuk menentukan kebijakan yang akan digunakan. Setelah menentukan kebijakan yang akan dilakukan maka akan dianalisis dan didiskusikan hasilnya kemudian dikembangkan.

\section{Pelaksanaan Anggaran}

Pengeluaran pembiayaan di MTs Al-Ikhlas Campaka menunjukkan bahwa penggunaan keuangan sekolah harus berdasarkan proposal kegiatan yang sesuai dengan RKAS di masukkan ke bagian terkait. Bagian Terkait mohon ijin dan pemberitahuan kepada kepala sekolah untuk diteliti dan merekomendasikan ke bagian keuangan. Suatu kegiatan direkomendasikan atau tidak oleh kepala sekolah tergantung kebijaksanaan kepala sekolah dengan mempertimbangkan RKAS yang telah ditetapkan.

Pembiayaan merupakan bagian dari kegiatan sekolah yang harus dilakukan dengan hati-hati. Mewujudkan pembiayaan yang efektif dan efisien bukan masalah yang mudah. Bagian keuangan harus dapat menghemat semua pengeluaran dana. 
Dana yang dikeluarkan harus sesuai dengan kebutuhan yang telah ditetapkan dalam RKAS. Kebutuhan yang ada di RKAS jika dirasa perlu untuk direvisi maka direvisi, atau bahkan ditunda atau dibatalkan.Tidak semua anggaran yang diajukan dapat terlaksana, karena kepala sekolah harus mempelajari setiap anggaran yang ada, jika terlalu besar maka harus dikurangi, jika terlalu kecil maka perlu ditambah atau bahkan di tunda atau dibatalkan. Kebijaksanaan tersebut dijalankan dengan tujuan untuk menghemat anggaran.

Persamaan antara pelaksanaan anggaran menurut penelitian ini dengan pelaksanaan anggaran menurut Tiina Itnoken dalam penelitiannya yang berjudul The Politics of School District Budgeting: Using Simulations to Enhance Student Learning adalah dalam pelaksanaan anggaran dapat berubah dari yang telah ada di rencana anggaran dengan alasan mendahulukan kegiatan yang lebih penting dengan mempertimbangkan skala prioritas. Pelaksanaan anggaran memerlukan anggaran berimbang antara penerimaan dan pengeluaran anggaran. Anggaran berimbang dilaksanakan dengan cara menghemat semua pengeluaran berdasarkan anggaran yang telah ditetapkan dan menambah pemasukan atau sumber dana pendidikan yang lain.

\section{Pengawasan dan Pertanggungjawaban Pembiayaan Pendidikan}

Pengawasan dan pertanggungjawaban pembiayaan pendidikan sangat diperlukan untuk mengukur efisiensi dan kefektifan. Pengawasan pembiayaan pendidikan di MTs Al-Ikhlas Campaka dilakukan oleh kepala sekolah dan yayasan . Pertanggungjawaban pembiayaan pendidikan di MTs Al-Ikhlas Campaka diserahkan oleh bendahara sekolah kepada Kepala sekolah . Kemudian dari kepala Sekolah akan mempertanggungjawabkan kepada komite sekolah dan yayasan.

Persamaan penelitian menurut Itkonen dalam penelitiannya yang berjudul The Politics of School District Budgeting: Using Simulations to Enhance Student Learning dengan pengelolaan pembiayaan di MTs Al-Ikhlas Campaka adalah pengawasan dan pertanggungjawaban harus di informasikan kepada pihak-pihak yang berkepentingan. Pengawasan dan pertanggungjawaban pembiayaan pendidikan di MTs Al-Ikhlas Campaka ditujukan kepada warga sekolah, komite sekolah dan yayasan sedangkan menurut Itkonen pengawasan dan pertanggungjawaban 
ditujukan kepada anggota kelompok dan kelas yang lain untuk dimintai tanggapan guna memperbaiki sistem anggaran yang sudah direncanakan.

\section{Hambatan dan Pendukung dalam pengelolaan pembiayaan di MTs Al-Ikhlas Campaka}

Hambatan yang dihadapi dalam pengelolan pembiayaan adalah faktor terhambatnya masuknya sumber dana yaitu keterlambatan siswa dalam pembayaran SPP dan tidak lancarnya turunnya dana bantuan dari pemerintah yaitu dana BOS. Faktor pendukung dalam pengelolaan pembiayaan adalah sekolah diberi kewenangan untuk mengatur pengelolaan pembiayaan di MTs Al-Ikhlas Campaka, jadi sekolah akan dapat mengatur dan merencanakan kegiatan dalam menunjang penyelenggaraan proses pendidikan. Tim pengelola keuangan juga merupakan faktor penting dalam pengelolaan pembiayaan di MTs Al-Ikhlas Campaka. Jujur dan Transparan adalah modal utama dalam pengelolaan pembiayaan di MTs AlIkhlas Campaka sehingga pengelolan pembiayaan terhindar dari penyelewengan dan kecurangan.

Hambatan pengelolaan pembiayaan di MTs Al-Ikhlas Campaka adalah sebagian siswa yang belajar di sekolah berasal dari keluarga kurang mampu dan berpendidikan rendah, hal ini menyebabkan rendahnya kemampuan mengakses informasi yang berasal dari sekolah dan pembiayaan yang mengandalkan subsidi dari pemerintah. Subsidi dari pemerintah yang berupa dana BOS yang turunnya tidak lancar akan mengurangi keefektifan pembiayaan. Faktor pendukungnya adalah dengan menggunakan sistem desentralisasi akan membantu sekolah untuk mengatur pembiayaannya sendiri dan tidak tergantung pada yayasan maupun pemerintah. Dalam penelitian ini penulis mencoba untuk menawarkan hasil penelitian agar pengelolaan pembiayaan di MTs Al-Ikhlas Campaka dapat berjalan sesuai dengan rencana. Model hasil penelitian yang ditawarkan :

a. Penyusunan anggaran yang baik akan membantu dalam pengelolaan pembiayaan sehingga mutu pendidikan di sekolah semakin meningkat.

b. Pengelolan pembiayaan di sekolah meliputi pengelolaan sumber dana dan pengelolaan alokasi dana. 
c. Pengelolaan pembiayaan harus dapat dipertanggungjawabkan, transparan, efektif dan efisien.

Transparansi dalam pengelolaan pembiayaan akan meningkatkan kepercayaan dari orang tua, masyarakat, yayasan dan pemerintah dalam penyelenggaraan seluruh program sekolah.

\section{KESIMPULAN}

Berdasarkan hasil penelitian yang telah drlaksanakan dengan judul "Pengelolaan Pembiayaan di MTs Al-Ikhlas Campaka " dapat ditarik kesimpulan sebagai berikut :

1. Pengelolaan Pembiayaan di MTs Al-Ikhlas Campaka dilaksanakan dengan proses :

a. Penganggaran (Perencanaan anggaran )

Pengangaran pembiayaan di MTs Al-Ikhlas Campaka telah dilaksanakan secara baik dan transparan.

b. Sumber Pembiayaan di MTs Al-Ikhlas Campaka diperoleh dari beberapa sumber yaitu :

(1) sumber dana dari masyarakat (SPP)

(2) sumber dana dari pemerintah berupa dana BOS

c. Pelaksanaan pembiayaan di MTs Al-Ikhlas Campaka berdasarkan anggaran yang sudah dibuat (RKAS).

d. Pengawasan dan Pertanggungjawaban pembiayaan dilakukan kepala sekolah dan yayasan.

2. Pengelolaan pembiayaan di MTs Al-Ikhlas Campaka sudah dilaksanakan secara transparan, efektif dan efisien. Pada saat perencanaan sudah melibatkan pihak pihak yang mewakili bagian- bagian yang ada disekolah.

3. Pengelolaan pembiayaan di MTs Al-Ikhlas Campaka juga masih ada kekurangannya yaitu belum semua pos dituangkan dalam RKAS, karena masih ada pengeluaran diluar RKAS untuk proses kelancaran KBM.

4. Faktor pendukung dan Penghambat

\section{a. Faktor Pendukung}

Faktor pendukung dalam pengelolalan pembiayaan di MTs Al-Ikhlas Campaka adalah sekolah berhak mengatur pembiayaan sekolah sesuai dengan kebutuhan 
sekolah tanpa tergantung seutuhnya pada pihak yayasan. Pencairan dana akan lebih cepat karena tidak melalui proses panjang. Tenaga-tenaga pengelola pembiayaan yang dapat diandalkan menjadikan pengelolaan pembiayaan dapat berjalan lancar baik dari segi administrasi maupun dari pelaksanaan.

b. Faktor Penghambat

Faktor penghambat dalam pengelolaan pembiayaan di MTs Al-Ikhlas Campaka adalah tidak lancarnya sumber dana pembiayaan baik turunnya dana BOS maupun keterlambatan siswa dalam pembayaran SPP.

\section{DAFTAR PUSTAKA}

Akdon, Deddy, dan Deni, Manajemen Pembiayaan Pendidikan, Bandung: Remaja

Rosdakarya, 2017.

Lexy J Moleong, 2014. Metodologi Penelitian Kualitatif. Bandung: PT Remaja Rosdakarya .

Mahmud H. 2011. Metode Penelitian Pendidikan. Bandung: CV Pustaka Setia.

Milles dan Huberman. 1992. Analisis Data Kualitatif, Jakarta: Universitas Indonesia Press.

Nanang Fattah. 2012. Ekonomi \& Pembiayaan Pendidikan. Bandung: PT Remaja Rosdakarya

Offset.

Suhardan, Riduwan, Enas. 2012. Ekonomi dan Pembiayaan Pendidikan. Bandung: Alfabeta .

Sutama. 2015. Metode Penelitian Pendidikan Kuantitatif, Kualitatif, PTK, R \& D. Kartasur: Fairuz Media 